\title{
PENGARUH PEMBERIAN TEPUNG IKAN DALAM COMPLATE FEEDTERHADAP KONSUMSI PAKAN DOMBA EKOR GEMUK (DEG)
}

\author{
Arya Adhi Prasetyo1, Dyanovita Alkurnia2*, Arif Arya Hertanto3 \\ Fakultas Peternakan Universitas Islam Lamongan. \\ ${ }^{*}$ Corresponding E-mail: dyanovita@unisla.ac.id
}

\begin{abstract}
ABSTRAK
Penelitian ini bertujuan untuk mengetahui pengaruh pemberian tepung ikan dalam complete feed terhadap konsumsi pakan Domba Ekor Gemuk (DEG). Materi pada penelitian ini adalah 8 Domba Ekor Gemukdengan pengelompokan menjadi 2 kelompok berdasarkan jenis kelamin yaitu 4 ekor Jantan dan 4 ekor Betina, pakan yang digunakan pada penelitian ini adalah complete feed yaitu P0 sebagai kontrol dengan $0 \%$ tepung ikan, P1 dengan 5\% tepung ikan, P2 dengan 10\% tepung ikan dan P3 dengan 15\% tepung ikan. Hasil peenelitian ini menunjukan bahwa pemberian tepung ikan dalam complete feed tidak berpengaruh nyata $(\mathrm{P}>0.05)$ terhadap Konsumsi Pakan P0 $\left(1014,21 \pm 173,95 \mathrm{~g} / \mathrm{kg}\right.$ bobot badan $\left.{ }^{0.75}\right)$, P1 $\left(751,97 \pm 46,62 \mathrm{~g} / \mathrm{kg}\right.$ bobot badan $\left.{ }^{0.75}\right)$, P2 $\left(780,49 \pm 49,42 \mathrm{~g} / \mathrm{kg}\right.$ bobot badan $\left.{ }^{0.75}\right)$, P3 $(718,23 \pm 70,03 \mathrm{~g} / \mathrm{kg}$ bobot badan $\left.{ }^{0.75}\right)$, Konsumsi Protein P0 $\left(12,94 \pm 0,60 \mathrm{~g} / \mathrm{kg}\right.$ bobot badan $\left.{ }^{0.75}\right), \mathrm{P} 1 \quad(11,76 \pm 0,52 \mathrm{~g} / \mathrm{kg}$ bobot badan $\left.{ }^{.75}\right)$, P2 $\left(12,63 \pm 0,64 \mathrm{~g} / \mathrm{kg}\right.$ bobot badan $\left.{ }^{0.75}\right), \mathrm{P} 3\left(12,27 \pm 0,32 \mathrm{~g} / \mathrm{kg}\right.$ bobot badan $\left.{ }^{0.75}\right)$ dan Konsumsi Energi P0 (2307,12 $\pm 108,31$ kkal), P1 $(2008,63 \pm 87,62$ kkal), P2 $(2141,98 \pm 107,91$ kkal), P3 $(2088,60 \pm 53,78 \mathrm{kkal})$ dan terdapat pengaruh nyata $(\mathrm{P}<0,05)$ terhadap Konsumsi Bahan Kering P0 $\left(77,76 \pm 3,65 \mathrm{~g} / \mathrm{kg}\right.$ bobot badan $\left.{ }^{0.75}\right)$, P1 $\left(59,84 \pm 2,61 \mathrm{~g} / \mathrm{kg}\right.$ bobot badan $\left.{ }^{0.75}\right)$, P2 $(66,35 \pm 3,34 \mathrm{~g} / \mathrm{kg}$ bobot badan $\left.^{0.75}\right)$, P3 $\left(64,27 \pm 1,65 \mathrm{~g} / \mathrm{kg}\right.$ bobot badan $\left.{ }^{0.75}\right)$. Dari penelitian ini dapat disimpulkan bahwa pemberian tepung ikan dalam complete feed tidak berpengaruh nyata terhadap konsumsi pakan, konsumsi protein dan Konsumsi Energi $(P>0.05)$ dan berpengaruh nyata terhadap Konsumsi Bahan Kering $(P<0,05)$.
\end{abstract}

Kata Kunci: tepung ikan; domba ekor gemuk

\section{EFFECT OF FEEDING FISHMEAL IN COMPLATE FEED ON FEED CONSUMPTION OF FAT TAIL SHEEP (DEG)}

\begin{abstract}
This study aims to determine the effect of giving fish meal in complete feed to the consumption of fat tail sheep. The material in this study were 8 Fat Tail Sheep with grouping into 2 groups based on sex, 4 male and 4 female, the feed used in this study was complete feed, P0 as a control with $0 \%$ fish meal, P1 with fish meal 5\%, P2 with 10\% fish meal and P3 with 15\% fish meal. The results of this study indicate that the provision of fish meal in complete feed has no significant effect $(P>0.05)$ on P0 Feed Consumption $\left(1014.21 \pm 173.95 \mathrm{~g} / \mathrm{kg}\right.$ bobot badan $\left.{ }^{0.75}\right), P 1\left(751.97 \pm 46.62 \mathrm{~g} / \mathrm{kg}\right.$ bobot badan $\left.{ }^{0.75}\right), P 2(780.49 \pm 49.42 \mathrm{~g} / \mathrm{kg}$ bobot badan $\left.{ }^{0.75}\right), P 3\left(718.23 \pm 70.03 \mathrm{~g} / \mathrm{kg}\right.$ bobot badan $\left.{ }^{0.75}\right)$, Consumption of Protein PO $(12.94 \pm 0.60 \mathrm{~g} / \mathrm{kg}$ bobot badan $\left.{ }^{0.75}\right), P 1\left(11.76 \pm 0.52 \mathrm{~g} / \mathrm{kg}\right.$ bobot badan $\left.{ }^{0.75}\right), P 2\left(12.63 \pm 0.64 \mathrm{~g} / \mathrm{kg}\right.$ bobot badan $\left.{ }^{0.75}\right), P 3$ $\left(12.27 \pm 0.32 \mathrm{~g} / \mathrm{kg}\right.$ bobot badan $\left.{ }^{0.75}\right)$ and Energy Consumption $P 0$ (2307.12 $\left.\pm 108.31 \mathrm{kkal}\right), \quad P 1$ (2008.63 $\pm 87.62 \mathrm{kkal}), P 2(2141.98 \pm 107.91 \mathrm{kkal}), P 3(2088.60 \pm 53.78 \mathrm{kkal})$ and there is not significant effect $(P>0.05)$ on the Consumption of Dry Material $P 0\left(77.76 \pm 3.65 \mathrm{~g} / \mathrm{kg}\right.$ bobot badan $\left.{ }^{0.75}\right), P 1$ $\left(59.84 \pm 2.61 \mathrm{~g} / \mathrm{kg}\right.$ bobot badan $\left.{ }^{0.75}\right), P 2\left(66.35 \pm 3.34 \mathrm{~g} / \mathrm{kg} \mathrm{bobot}{ }^{0.75}\right), P 3\left(64.27 \pm 1.65 \mathrm{~g} / \mathrm{kg}\right.$ bobot $\left.{ }^{0.75}\right)$. From this study it can be concluded that fish meal in complete feed does not contain real for Feed Consumption, Protein Consumption and Energy Consumption $(P>0.05)$ and real for Consumption of Dry Material $(P$ $<0.05)$.
\end{abstract}

Key words: fish meal; fat tail sheep

\section{PENDAHULUAN}

Domba merupakan salah satu jenis ternak yang banyak dipelihara oleh masyarakat Indonesia. Menurut data statistik Dirjen Peternakan (2020), populasi ternak domba di Indonesia pada mencapai 17.769 .084 ekor dan populasi domba yang ada di jawa timur mencapai 1.416.969 ekor. Salah satu jenis domba lokal yang ada di Indonesia adalah domba ekor gemuk. 
Domba ini sangat cocok untuk diternakkan dan dipelihara karena memiliki tingkat produktifitas yang lebih tinggi dibanding jenis domba lokal lain seperti domba ekor tipis (Khasanah 2007).

Kemampuan produksi ternak domba di Indonesia dapat ditingkatkan bila tata cara pemeliharaan secara ekstensif diubah ke semiintensif atau intensif (Mulyono dan Sarwono, 2004). Bila ditinjau dari aspek produksi, domba lokal mempunyai daya adaptasi yang tinggi terhadap kondisi lingkunganyang beriklim tropis termasuk pakan yang sangat jelek (Sodiq dan Abidin, 2003). Kelembaban yang dibutuhkan oleh domba untuk tumbuh adalah $60 \%-80 \%$ (Akhmad Sodiq dan Zainal Abidin, 2008).

Performa domba selain dipengaruhi oleh faktor genetik juga dipengaruhi oleh faktor lingkungan. Salah satu jenis faktor lingkungan yang sering menjadi kendala para peternak adalah pakan. Vosooghi-poostindoz et al. (2013) menyatakan bahwa kualitas pakan akan mempengaruhi konsumsi pakan, pertambahan bobot badan dan efisiensi pakan pada ternak.

Wahyuni dan Bijanti (2006) menjelaskan, Complete feed untuk menyediakan nutrisi secara komplit dan praktis dengan pemenuhan nilai nutrisi yang tercukupi. Pemberian complete feed harus memperhatikan kehidupan mikroba rumen karena pencerna serat kasar ini hidup pada kondisi derajat keasamaan netral, sehingga turunnya $\mathrm{pH}$ dalam rumen hendaknya dihindari agar tidak menurunkan kemampuan dalam mencerna serat kasar (Utomo, 2004).

Pakan sumber protein adalah pakan yang mengandung lebih dari $20 \%$ protein kasar (Achmadi, 2012). Tepung ikan mengandung protein yang cukup tinggi, sehingga bahan tersebut digunakan sebagi sumber utama protein pada pakan, disamping pakan lainnya. Selain sebagai sumber protein, tepung ikan juga digunakan sebagai sumber kalsium. Tepung ikan yang baik mempunyai kandungan protein kasar 58\%-68\%, air 5,5\%-8,5\%, serta garam 0,5\%-3,0\% (Boniran, 1999). Tepung ikan mempunyai variasi kualitas yang sangat tinggi, standarisasi pengolahan dan tingkat nutrien tepung ikan yang didatangkan dari luar negeri mempunyai kadar protein antara 55\%-65\%, lemak 5\%-7\% (NRC, 1994).

Berdasarkan uraian di atas, maka penulis tertarik untuk melakukan penelitian tentang pengaruh pemberian tepung ikan dalam complete feed terhadap konsumsi pakan Domba Ekor Gemuk (DEG). Manfaat dari penelitian adalah memperoleh informasi mengenai bagaimanakah pengaruh pemberian tepung ikan dalam complete feed terhadap konsumsi pakan Domba Ekor Gemuk (DEG).

\section{MATERI DAN METODE Materi}

Materi pada penelitian ini adalah Domba Ekor Gemuk dengan jumlah 4 ekor Jantan dan 4 ekor Betina, dengan rata-rata bobot domba 18,88 $\pm 3,06 \mathrm{~kg}$. Penelitian ini dilaksanakan pada 16 Maret sampai dengan bulan 12 April tahun 2020. Pelaksanaan penelitian berlokasi di Peternakan Pendowo Farm Desa Tanjung Kawasan Perumahan Witara Kabupaten Lamongan, sedangkan analisis Proksimat di Laboratorium Konsultasi dan Pelatihan Unit Pengujian Veteriner dan Analisi Pakan Universitas Airlangga Surabaya.

\section{Metode}

Penelitian ini menggunakan Rancangan Acak Kelompok dengan 4 perlakuan dan 2 pengelompokan berdasarkan jenis kelamin, perlakuan tersebut adalah tingkat penggunan tepung ikan dalam complete feed yaitu P0 (0\%), P1 (5\%), P2 (10\%) dan P3 (15\%). Masingmasing domba dalam tiap kelompok diberi pakan complete feed yang berbeda sesuai perlakuan, jumlah pakan harian dalam bentuk BKyang diberikan pada masing-masing domba sebanyak 4,3\% dariberat badan. Konsumsi BK ini masih dalam kisaran normal. Ranjhan (1981) menyatakan bahwa konsumsi BK sekitar $3-5 \%$ dari bobot hidup. Pemberian pakan dilakukan sebanyak dua kali sehari yaitu pada pukul 06.00-07.00 pagi dan 16.00-17.00 sore dengan Air minum diberikan secara adlibitum.

Pengukuran konsumsi pakan dan konsumsi zat makanan dilakukan dengan cara mengukur jumlah pakan yang diberikan (g) dan jumlah pakan sisa (g). Konsumsi zat makanan dihitung menggunakan rumus sebagai berikut (Marjuki, 2008): 
Zat makanan $\left(\mathrm{g} / \mathrm{kg} \mathrm{BB}^{0,75}\right)=\frac{\text { zzat makanan pemberian }(\mathrm{g})-\sum \text { sisa zat makanan }}{\text { Bobot Badan }(\mathrm{kg})^{0,75}}$

Tabel 1. Komposisi bahan pakan pada masing-masing perlakuan

\begin{tabular}{|c|c|c|c|c|}
\hline BAHAN PAKAN & $\mathrm{PO}(\mathrm{Kg})$ & $\mathrm{P} 1(\mathrm{Kg})$ & $\mathrm{P} 2(\mathrm{Kg})$ & P3 (Kg) \\
\hline Gaplek & 4 & 4 & 4 & 4 \\
\hline Bungkil Kopra & 19 & 16 & 14 & 16 \\
\hline Jagung & 7 & 7 & 7 & 5 \\
\hline Jerami kangkung & 9 & 6 & 6 & 6 \\
\hline Bungkil Kedelai & 18 & 14 & 10 & 6 \\
\hline Dedak Padi & 7 & 7 & 7 & 7 \\
\hline Pollard & 10 & 10 & 7 & 7 \\
\hline Slamper Jagung & 5 & 5 & 4 & 3 \\
\hline Janggel Jagung & 15 & 20 & 25 & 25 \\
\hline Kulit Kacang Hijau & 4 & 4 & 4 & 4 \\
\hline Cattel Mix & 1 & 1 & 1 & 1 \\
\hline Molases & 1 & 1 & 1 & 1 \\
\hline Tepung Ikan & 0 & 5 & 10 & 15 \\
\hline Total & 100 & 100 & 100 & 100 \\
\hline
\end{tabular}

Tabel 2. Kandungan zat makanan yang digunakan dalam penelitian

\begin{tabular}{lcccc}
\hline \multicolumn{1}{c}{ Zat Makanan } & $\mathrm{P} 0(0 \%)$ & $\mathrm{P} 1(5 \%)$ & $\mathrm{P} 2(10 \%)$ & $\mathrm{P3}(15 \%)$ \\
\hline BK (\%) & 85,77 & 78,77 & 78,72 & 77,95 \\
ABU (\%) & 10,76 & 9,98 & 9,56 & 9,89 \\
PK (\%) & 14,27 & 14,89 & 14,99 & 14,88 \\
LK (\%) & 5,75 & 6,12 & 6,29 & 6,6 \\
SK (\%) & 16,06 & 16,8 & 17,02 & 16,96 \\
Ca (\%) & 1,01 & 1,43 & 1,46 & 1,12 \\
TDN (\%) & 73,57 & 75,94 & 75,98 & 75,84 \\
ME (Kcal/kg) & 2544,57 & 2543,74 & 2541,36 & 2533,23 \\
\hline
\end{tabular}

Sumber : Unit pengujian veteriner dan analisis pakan FKH Unair, (2020).

Data yang terkumpul dianalisis dengan sidik ragam sesuai pola Rancangan Acak Kelompok dan Uji Jarak Duncan.

\section{HASIL DAN PEMBAHASAN}

Hasil analisis statistik menunjukkan bahwa pemberian tepung ikan dalam complete feed tidak berpengaruh nyata terhadap Konsumsi Pakan, Konsumsi Protein dan Konsumsi Energi $(P>0.05)$ dan berpengaruh nyata terhadap Konsumsi Bahan Kering Zat Makanan $(P<0,05)$.

Tabel 3. Rata - rata konsumsi pakan, bahan kering, protein kasar dan konsumsi energi

\begin{tabular}{lllll}
\hline \multirow{2}{*}{ Parameter } & \multicolumn{4}{c}{ Tepung lkan } \\
\cline { 2 - 5 } & \multicolumn{1}{c}{$0 \%$} & \multicolumn{1}{c}{$5 \%$} & $10 \%$ & \multicolumn{1}{c}{$15 \%$} \\
\hline $\begin{array}{l}\text { Konsumsi Pakan } \\
\text { (g/kg bobot badan }^{0.75} \text { ) }\end{array}$ & $1014,21 \pm 173,95$ & $751,97 \pm 46,6$ & $780,4 \pm 49,42$ & $718,23 \pm 70,0$ \\
Konsumsi Bahan Kering $_{(\text {g/kg bobot badan }}^{0.75}$ ) & $77,76 \pm 3,65$ & $59,84 \pm 2,61$ & $66,35 \pm 3,34$ & $64,27 \pm 1,65$ \\
Konsumsi Protein Kasar $_{(\text {g/kg bobot badan }}{ }^{0.75}$ ) & $12,94 \pm 0,60$ & $11,76 \pm 0,52$ & $12,63 \pm 0,64$ & $12,27 \pm 0,32$ \\
Konsumsi Energi & $2307,12 \pm 108,31$ & $2008,63 \pm$ & $2141,98 \pm 10$ & $2088,60 \pm 53$, \\
\hline
\end{tabular}


Pada tabel 3 menunjukkan konsumsi pakan tidak menunjukan perbedaan secara nyata $(P>0,05)$ diduga hal ini karena kandungan nutrisi ransum yang diberikan antar perlakuan adalah sama, secara tidak langsung menunjukkan bahwa seluruh perlakuan pemberian tepung ikan pada complete feed tidak merubah palatabilitas. Hal ini berarti bahwa pemberian tepung ikan pada complete feed tidak mempengaruhi konsumsi pakan domba, seperti yang dinyatakan Kusumaningrum, (2009) Tinggi rendahnya konsumsi pakan pada ternak ruminansia sangat dipengaruhi oleh faktor eksternal yaitu: tempat tinggal (kandang), palatabilitas (tingkat kesukaan), konsumsi nutrisi, bentuk pakan dan faktor internal yaitu: selera, status fisiologi, bobot tubuh dan produksi ternak itu sendiri. Hussein dan Jordan (1991) melaporkan bahwa subtitusi bungkil kedele atau kombinasi bungkil kedele dan urea dalam pakan dengan tepung ikan dapat menghasilkan pertambahan bobot badan lebih tinggi. Rocha et al. (1995) menyatakan bahwa tepung ikan merupakan bahan pakan sumber ruminally undegradable protein (RUP) dan kaya lisin dan methionin yang merupakan dua asam amino pembatas (limiting amino acids) pada ternak ruminansia. Blauwiekel et al. (1992) melaporkan bahwa tepung ikan umumnya mengandung RUP lebih dari $70 \%$ sedangkan bungkil kedele mengandung RUP kurang dari $45 \%$ dan tepung ikan dapat memasok lisin dan methionin masing-masing dua dan empat kali lipat lebih besar dibanding bungkil kedelai.

Konsumsi bahan kering dapat dilihiat pada tabel 3 menunjukkan hasil yang tidak berbeda nyata $(P>0,05)$ diduga disebabkan kandungan Bahan Kering pada proksimat pakan P0 $(85,77 \%)$ hampir sama P1 $(75,77 \%)$, P2 $(78,72 \%)$ dan P3 $(77,95 \%)$, hal tersebut diduga juga karena dalam komposisi ransum pada tabel 3.2, bungkil kopra, bungkil kedele dan jerami kangkung pada P0 hampir sama dibanding P1, P2 dan P3. Seperti yang dinyatakan Anggorodi, (1994) Faktor-faktor yang mempengaruhi daya cerna bahan pakan adalah bentuk fisik dari pakan, komposisi serat dari ransum, ukuran partikel pakan dan pengaruh perbandingan dengan zat lainnya.

Kemampuan mengkonsumsi bahan kering (BK) merupakan pembatas bagi ternak dalam upaya memenuhi kebutuhan akan zat-zat pakan yang diperlukan untuk hidup pokok, pertumbuhan dan reproduksi (Tillman et al., 1998). Dijelaskan lebih lanjut bahwa konsumsi BK memegang peranan penting, karena dari BK tersebut ternak memperoleh energi, protein, vitamin dan mineral. Salah satu hal yang perlu diperhatikan pada pemberian pakan domba adalah konsumsi BK untuk berbagai tingkat bobot badan sebagai pedoman dalam menentukan jumlah pakan yang harus disediakan (Herman, 1977).

Konsumsi bahan kering berdasarkan bobot badan metabolis pada tabel 3 menunjukkan hasil berkisar $59,84-77,76 \mathrm{~g} / \mathrm{kg} \mathrm{BB}^{0.75}$. Hasil yang diperoleh ini lebih tinggi bila dibandingkan dengan hasil penelitan Marjuki, (2008) yang menggunakan tepung ikan dalam pakan konsentrat pada kambing lokal betina jenis bligon atau jawa randu yaitu sebesar $58,54-65,32 \mathrm{~g} / \mathrm{kg} \mathrm{BB}^{0.75}$ diduga karena pada penelitian ini penggunaan tepung ikan lebih banyak, tepung ikan pada kecernaanya didalam rumen cenderung lebih cepat meninggalkan rumen karena kelarutannya rendah sehingga nutrisi dari tepung ikan dapat diserap lebih banyak di pasca rumen yakni pada usus halusnya .

Hasil penelitian konsumsi protein kasar terdapat pada tabel 3 menunjukkan hasil yang tidak berbeda nyata $(P>0.05)$ antar perlakuan disebabkan karena kandungan protein kasar ransum pada semua perlakuan yang tidak jauh berbeda yaitu 14,27\%-14,99\% (Tabel 3.3) jumlah kandungan protein tersebut masih dalam kisaran normal, Gatenby, (1991) menyebutkan, jumlah protein kasar minimum yang diperlukan domba untuk hidup pokok sebesar $8 \%$ dari bahan kering, sedangkan domba yang sedang tumbuh atau laktasi memerlukan protein kasar sejumlah $11 \%$ dari bahan kering. Konsumsi protein kasar berdasarkan bobot badan metabolit pada penelitian ini berkisar $11,76-12,94 \mathrm{~g} / \mathrm{kg} \mathrm{BB}^{0.75}$. Hasil ini lebih tinggi dibandingkan dengan hasil penelitan Marjuki, (2008) yang menggunakan tepung ikan dalam pakan konsentrat pada kambing lokal betina jenis bligon atau jawa randu yaitu sebesar 8,83-9,69 $\mathrm{g} / \mathrm{kg} \mathrm{BB}^{0.75}$.

Rangkuti, (2011) menyebutkan bahwa konsumsi protein kasar yang tinggi dipengaruhi oleh beberapa faktor, salah satunya adalah jenis bahan pakan khususnya bahan penyusun konsentrat. Bahan pakan penyusun konsentrat merupakan pangan penguat dengan kadar serat 
kasar rendah dan banyak mengandung protein dan energi. Palatabilitas pakan dan jumlah pakan yang dimakan akan meningkatkan konsumsi protein yang lebih banyak dari kebutuhan minimalnya sehingga dapat berguna untuk meningkatkan bobot badan.

Ternak ruminansia selain membutuhkan protein juga membutuhkan evaluasi nilai energi. Hewan yang sedang tumbuh membutuhkan energi untuk memelihara tubuh (hidup pokok), memenuhi kebutuhan akan energi mekanik untuk gerak otot dan sintesa jaringan-jaringan baru (Tillman et al. 1998). Konsumsi energi tidak berbeda nyata $(P>0.05)$ pada penelitian ini berkisar 2008,63 - 2307,12 Kcal atau setara dengan 2,01-.2,31 Mcal karena antar perlakuan nilai energi hampir sama. Hasil ini sesuai dengan kebutuhan harian zat makanan NRC (1985) pada BB 20 $30 \mathrm{Kg}$ yaitu 1,80-2,44 Mcal. Konsumsi energi dipengaruhi oleh beberapa faktor yaitu umur, bangsa, ukuran tubuh, aktivitas, laju pertumbuhan, metabolisme dan suhu lingkungan (Ensminger et al. 1990). Namun dari sejumlah energi yang dikonsumsi tidak semua diretensi menjadi produk karena sebagian akan diekskresikan sebagai feses, urin, gas methan dan panas metabolisme (McDonald et al. 2010). Umumnya ternak ruminansia kalau konsumsi energi termanfaatkan dengan baik maka akan berpengaruh pada konsumsi zat makanan lainnya seperti protein, mineral dan vitamin (Rudiah, 2011).

\section{KESIMPULAN}

Kesimpulan dari hasil penelitian yang telah dilakukan, disimpulkan bahwa dalam pemberian tepung ikan pada complete feed tidak berpengaruh nyata terhadap konsumsi pakan Domba Ekor Gemuk, Penggunaan tepung ikan dapat digunakan menjadi bahan campuran complete feed.

\section{DAFTAR PUSTAKA}

Achmadi. J. 2012. Aspek Komparatif Nutrisi Ternak Monogastrik dan Ruminansia. Penerbit Universitas Diponegoro, Semarang.

Akhmad Sodiq dan Zainal Abidin. 2008. Sukses Penggemukan Domba. Agro Media. Jakarta. $51 ; 103-104$.

Anggorodi, R. 1994. Ilmu Makanan Ternak Umum. Penerbit Gramedia Pustaka Utama. Jakarta.

Blauwiekel, R., S. Xu, and J. H. Harrison. 1992. The use of cereal grains and by-roduct feeds to meet the amino acid requirements of dairy cattle. In: Proc. 27th Pacific Northwest Animal Nutrition Conference. Spokane, WA. pp 225-236.

Boniran, S. 1999. Quality control untuk bahan baku dan produk akhir pakan ternak. Kumpulan Makalah Feed Quality Management Workshop. American Soybean Association dan Balai Penelitian Ternak. hlm. 2-7.

Direktorat Jendral Peternakan Dan Kesehatan Hewan. Buku Stastika Peternakan Dan Kesehatan Hewan 2018 Jakarta. Dalam http://ditjenpkh.pertanian.go.id

Ensminger, M. E. 2002. Sheep and Goat Science. Sixth Edition. Interstate Publisher, Inc.

Gatenby, R. M. 1991. The Tropical Agriculturist Sheep. Mc Millan Education Ltd., London and Basingtone.

Herman, R. 1977. Kebutuhan bahan kering berdasarkan bobot badan. Buletin Makanan Ternak. $3: 148-152$.

Hussein, H.S., and R.M. Jordan. 1991. Fish meal as a protein supplement in ruminant diets. A Review. J. Anim. Sci. 69 : 2147- 2156.

Khasanah N. 2007. Hubungan pertambahan bobot badan harian dengan perubahan ukuran linier tubuh pada bangsa domba dan jenis kelamin yang berbeda [skripsi]. Bogor (ID): Institut Pertanian Bogor.

Kusumaningrum, B.L. 2009. Kajian Kualitas Ransum Kambing Peranakan Ettawa di Balai Pembibitan dan Budidaya Ternak Ruminansia Kendal. Laporan Praktek Kerja Lapangan Fakultas Peternakan Universitas Diponegoro. Semarang.

Marjuki. 2008. Penggunaan Tepung Ikan dalam Pakan Konsentrat dan Pengaruhnya Terhadap Pertambahan Bobot Badan Kambing Betina. Universitas Brawijaya. Malang

McDonald P, Edwards RA, Greenhalgh JFD, Morgan CA, Sinclair LA, Wilkinson RG. 2010. Animal Nutrition. Ed ke-7. England (US) : Imprint Pearson Education Prontice Hill. 
Mulyono, S. dan B. Sarwono, 2004. Penggemukan Kambing Potong. Penebar Swadaya. Jakarta

National Research Council (NRC). 1985. Nutrient Requirements of Sheep. National Academy Press, Washington DC.

National Research Council (NRC). 1994. Nutriement Requirement of Poultry. 9th Revised Ed. National Academy Press, Washington DC.

Rangkuti, J.H. 2011. Produksi dan Kualitas Susu Kambing Peranakan Ettawa (PE) pada Kondisi Tatalaksana yang Berbeda. Departemen Ilmu Produksi dan Teknologi Peternakan. Fakultas Peternakan. Institut Pertanian Bogor, Bogor.

Ranjhan, S. K. 1981. Animal Nutrition in The Tropics. Vicas Publishing House PVT Ltd. New Delhi.

Rocha, A., M. Carpena, B. Triplett, D.W. Forrest, and R.D. Randel. 1995. Effect of Ruminally Undegradable Protein from Fish Meal on Growth and Reproduction of Peripuberal Brahman Bulls. J. Anim. Sci. 73 : 947-953.

Rudiah. 2011. Respon kambing kacang jantan terhadap waktu pemberian pakan. Media Litbang Sulteng IV (1) : 67 - 74, Juni 2011.

Sodiq, A. dan Z. Abidin.2002. Penggemukan Domba. Agro Media Pustaka. Jakarta.

Tillman, A.D., H. Hartadi, S. Reksohadiprodjo, S. Prawirokusumo, dan S. Lebdosukojo, 1998. IImu Makanan Ternak Dasar. Cetakan ke-4. Gadjah Mada University Press, Yogyakarta.

Utomo, R. 2004. Pengaruh penggunaan jerami padi fermentasi sebagai bahan dasar pembuatan pakan komplit pada kinerja domba. Buletin Peternakan 28(4): 162-171.

Vosooghi-poostindoz, V., A.R. Foroughi, A. Delkhoroshan, M.H. Ghaffari, R. Vakili dan A.K. Soleimani. 2013. Effect of different levels of protein with or without probiotics on growth performance and blood metabolite rensponse during pre- and post-weaning phases in male Kurdi lambs. Small Ruminant Research. $117: 1-9$.

Wahyuni, dan R. Bijanti. 2006. Uji Efek Samoing Formula Pakan Komplit Terhadap Fungsi Hati dan Ginjal Pedet Sapi Friesan Holstein. MKH. 22(3) : 174- 178. 